\title{
Molecular diagnosis of Ehrlichia canis infection in dogs with uveitis
}

\section{Diagnóstico molecular da infecção por Ehrlichia canis em cães com uveíte}

\author{
Jéssica Fontes Veloso ${ }^{1 *}$; Leonardo Sauer ${ }^{2}$; Arianne Pontes Oriá3; \\ Deusdete Conceição Gomes Junior"4; Ana Cláudia Santos Raposo ${ }^{5}$; \\ Camila Fernanda Oliveira Andrade ${ }^{2}$; Thais Nascimento de Andrade Oliveira ${ }^{1}$; \\ Renata Santiago Alberto Carlos ${ }^{6}$
}

\begin{abstract}
Canine monocytic ehrlichiosis (CME) is an infectious disease caused by a gram-negative bacterium Ehrlichia canis that has a high global prevalence that leads to high rates of morbidity and mortality in dogs. Among the clinical changes, ophthalmic diseases can lead to permanent blindness and it can be an important clinical sign. The objective of this study was to perform nested polymerase chain reaction (PCR) to diagnose E. canis infection in dogs with bilateral uveitis from the Veterinary Hospital of the Santa Cruz State University. Blood samples were collected and DNA for the molecular diagnosis was extracted from 66 adult dogs of both genders and mixed breeds diagnosed with bilateral uveitis. Thirtyfive $(53 \%)$ dogs showed positive results and presented with iridocyclitis, posterior uveitis, panuveitis, or uveitis with secondary glaucoma. This study demonstrates that nested PCR is an important tool for the differential diagnosis of dogs with bilateral uveitis, as it provides evidence of the infectious agent in the animal.
\end{abstract}

Key words: Eye. Glaucoma. Infectious Uveitis. Nested PCR. Rickettsia.

\section{Resumo}

Erliquiose Monocítica Canina (EMC) é uma doença infecciosa causada por uma bactéria gram negativa da espécie Ehrlichia canis, que possui alta prevalência mundial e conduz a elevadas taxas de morbidade e mortalidade em cães. Dentre as alterações clínicas, as oftalmopatias podem levar a cegueira permanente e é ser um importante sinal clínico. Objetivou-se realizar nested-PCR para diagnosticar infecção por E. canis em cães portadores de uveíte bilateral provenientes da casuística do Hospital Veterinário da Universidade Estadual de Santa Cruz. Sessenta e seis cães adultos, de ambos sexos e raças variadas, diagnosticados com uveíte bilateral foram submetidos a coleta de sangue e o DNA para realização do diagnóstico molecular foi extraído destas amostras. Foram positivos no teste 35 (53\%) cães, que apresentaram iridociclite, uveíte posterior, panuveíte ou uveíte com glaucoma secundário. Esse estudo demonstra a nested-PCR como ferramenta importante no diagnóstico diferencial de cães com uveíte

\footnotetext{
1 Discentes de Doutorado, Universidade Estadual de Santa Cruz, UESC, Ilhéus, BA, Brasil. E-mail: jessicaveloso@live.com; thaisnaoliveira@gmail.com

2 Médicos Veterinários Autônomos, Bahia, BA, Brasil. E-mail: leosauer11@hotmail.com; camila.f.o.andrade@gmail.com

3 Prof ${ }^{\text {, }}$ Escola de Medicina Veterinária e Zootecnia, Universidade Federal da Bahia, UFBA, Salvador, BA, Brasil. E-mail: arianneoria@ufba.br

4 Prof ${ }^{a}$, Universidade Federal do Oeste da Bahia, UFOB, Barra, BA, Brasil. E-mail: deusvet@yahoo.com.br

5 Discente de Doutorado, UFBA, Salvador, BA, Brasil. E-mail: anaclaudiaraposo.acr@gmail.com

6 Prof ${ }^{a}$, Universidade Estadual de Santa Cruz, UESC, Bahia, BA, Brasil. E-mail: rsacarlos@uesc.br

* Author for correspondence
} 
bilateral, por proporcionar a comprovação do agente infeccioso no organismo do animal.

Palavras-chave: Olho. Glaucoma. Uveíte infecciosa. Nested PCR. Rickettsia.

\section{Introduction}

Canine monocytic ehrlichiosis (CME) affects dogs and is caused by the bacterium Ehrlichia canis species; it is transmitted through the arthropod vector Rhipicephalus sanguineus lato sensu during its blood meal (DUMLER et al., 2001; VIEIRA et al., 2011). CME has been reported across all continents, but it is more frequently detected in temperate, tropical, and subtropical areas (DAGNONE et al., 2003; LABARTHE et al., 2003; RODRIGUEZVIVAS et al., 2005). In the state of Bahia, prevalence of $7.8 \%$ (CARVALHO et al., 2008), 11\% (CARLOS et al., 2011), and 25.6\% (GUEDES et al., 2015) has been reported by evaluating the canine populations with nested polymerase chain reaction (PCR).

Uveitis is the inflammatory alteration of the structures of the uveal tract, and it can occur as a consequence of systemic diseases. It is considered an important ophthalmic manifestation related to CME, as a consequence of vasculitis, deposition of immunocomplexes, and ocular haemorrhage of one or several ocular structures (MARTIN; STILES, 1998; HENDRIX, 2013). The immunocomplexes are deposited in local blood vessels and promote increased vascular permeability as well as imbalance of the ocular barriers. Therefore, influx of mononuclear inflammatory cells in the eye accentuates lesions in the uveal tract (HARRUS et al., 2001; HENDRIX, 2013). The inflammation is also increased by the activation of the arachidonic acid cascade associated with the injury of cell membranes, resulting in an increase in the concentrations of prostaglandins and leukotrienes (BISTNER, 1994).

In a study on 102 cases of uveitis in dogs, infectious diseases were responsible for $17.6 \%$ of the cases $(\mathrm{n}=18)$, and E. canis was serologically confirmed in $38.8 \%$ of the cases of infectious diseases (MASSA et al., 2002). In another study, indirect immunofluorescence and dot-blot enzymelinked immunosorbent assay (ELISA) used for the diagnosis of E. canis in 51 dogs with uveitis showed a prevalence of $66.67 \%$ and $86.27 \%$, respectively (ORIÁ et al., 2008).

In this context, molecular diagnosis using PCR for detecting the causative agent in tissues or blood increases diagnostic precision, assists in taxonomic classification, and allows early detection of infection and infecting species. Its main advantages in relation to serological methods are as follows: absence of cross-reactions and the possibility of defining that the infection is acute and not due to previous exposure (IQBAL et al., 1994; WEN et al., 1997; DAGNONE et al., 2003).

Since diagnosing the cause of uveitis is of great importance for initiating appropriate therapy and minimizing ophthalmic repercussions, the objective of this study was to perform a two-step PCR (nested PCR) that provides greater specificity and precision for the diagnosis of infection by E. canis in dogs with uveitis.

\section{Material and Methods}

\section{Ethical considerations}

This study was approved by the Ethics Committee on the Use of Animals from the State University of Santa Cruz (protocol 025/2013) as well as the rules of the Association for Research in Vision and Ophthalmology (ARVO).

\section{Animals}

In this study, we used 66 adult dogs of both genders and different breeds from the Ophthalmic Clinic of the Veterinary Hospital of the State University of Santa Cruz (HOSPVET/UESC) between August 2014 and August 2015; the dogs showed clinical signs of bilateral uveitis, except for one unilateral anophthalmic animal. 


\section{Ocular examination}

All of the ophthalmic tests were chosen and followed by the rules of the ARVO and methodology of Talieri et al. (2006).

For the ophthalmic evaluation, observation of the ophthalmic attachments, eye symmetry, positioning in the orbit and threat, and movement and obstacle tests were performed. Continuous action, using a yellow light flashlight, and direct and consensual pupil reflex were evaluated.

The Schirmer test was performed using standard strips (Ophthalmos ${ }^{\circledR}$ - São Paulo, SP, Brazil), and it was preceded by measurement of the intraocular pressure (IOP) with rebound tonometry (TONOVET Icare $\left.^{\circledR}\right)$, calibrated for measurement in dogs with standard deviation $\leq 1.0$. Structures such as eyelids, conjunctiva, sclera, pupils, and iris were evaluated using a biomicroscope with a slit lamp (Vision Class II BL IIIB/YZ30T Ramos Mejia ${ }^{\circledR}$ - São Paulo, SP, Brazil).

Evaluation of the back eye segment was performed using $1 \%$ tropicamide (Mydriacyl ${ }^{\circledR}$; Alcon - São Paulo, SP, Brazil) bilaterally, and it was repeated after $10 \mathrm{~min}$ to achieve complete mydriasis whenever necessary. The posterior segment was evaluated using an indirect binocular ophthalmoscope (OSF 1.0 Eyetec $^{\circledR}$ - São Carlos, SP, Brazil) and 20-D magnification lens (Eyetec ${ }^{\circledR}$ - São Carlos, SP, Brazil) and a panoptic direct ophthalmoscope (WelchAllyn ${ }^{\circledR}$ - Barueri, SP, Brazil).

The integrity of the cornea was evaluated using the fluorescein test (fluorescein strips; Ophthalmos ${ }^{\circledR}$ - São Paulo, SP, Brazil).

To select the 66 dogs with uveitis, we considered reduction of IOP, presence of ocular secretion, congestion of episcleral vessels, corneal abnormalities such as ciliary injection, edema, and the presence of keratic precipitates and flare and hyphemain the anterior chamber. Ophthalmoscopy was used to assess retinal detachments, hyper-reflexia, hemorrhages, and retinal vascular conditions.
PCR

\section{Collection of biological samples}

After the ophthalmic evaluation, $4 \mathrm{~mL}$ of blood was collected using cephalic or jugular vein puncture. The collected blood was conditioned in a tube with the anticoagulant EDTA and later stored in a freezer at $-20^{\circ} \mathrm{C}$ until PCR was performed.

\section{DNA extraction and quantification}

DNA was extracted from the whole-blood samples with the Easy DNA Kit, according to the manufacturer's instructions (Protocol 2; Invitrogen ${ }^{\circledR}$ - São Paulo, SP, Brazil).

The DNA extracts were quantified using the NanoDrop ${ }^{\circledR} 2000$ spectrophotometer and stored in the freezer at $-20^{\circ} \mathrm{C}$.

\section{Selection of primers and DNA amplification}

For the first step of DNA amplification, we selected primers ECC (5'-AGAACGAACGCTGGCGGCAAGC-3') and ECB (5'-CGTATTACCGCGGCTGCTGGCA-3'), which amplify part of the 16SrRNA gene of Ehrlichia spp. Then, for the identification of E. canis, we used primers ECAN -CAATTATTTATAGCCTCTGAGCTATAGGA-3') and

HE3

(5'-TATAGGTACCGTCATTATCTTCCCTAT-3'), according to the methodology described by Murphy et al. (1998).

For PCR, $5 \mu \mathrm{L}$ of the purified DNA, $0.4 \mathrm{mM}$ of each primer (ECC and ECB), 200mM of each dNTP, $5 \mathrm{mM}$ of $\mathrm{MgCl}_{2}, 1.6 \times$ PCR buffer (Invitrogen ${ }^{\circledR}$ - São Paulo, SP, Brazil), and 2.5U of Taq DNA polymerase (Invitrogen ${ }^{\circledR}$ - São Paulo, SP, Brazil) were used, yielding a final volume of $25 \mu \mathrm{L}$. The schedule used for the Applied Biosystems ${ }^{\circledR}$ ProFlex ${ }^{\mathrm{TM}}$ PCR System thermal cycler for the identification of the genetic sequence of the genus Ehrlichia was as follows: denaturation at $94^{\circ} \mathrm{C}$ for 
$3 \mathrm{~min}$, followed by 35 denaturation cycles at $94^{\circ} \mathrm{C}$ for $1 \mathrm{~min}$, annealing at $68^{\circ} \mathrm{C}$ for $2 \mathrm{~min}$, and extension at $72^{\circ} \mathrm{C}$ for $2 \mathrm{~min}$. For nested PCR, $1 \mu \mathrm{L}$ of the amplicon from the first PCR and $0.2 \mathrm{mM}$ of each primer (ECAN5 and HE3), 200mM of each dNTP, $5 \mathrm{mMof} \mathrm{MgCl}_{2}, 1.6 \times$ PCR buffer (Invitrogen ${ }^{\circledR}$ ), and 2.5U Taq DNA polymerase (Invitrogen ${ }^{\circledR}$ - São Paulo, SP, Brazil) were used, yielding a final volume of $25 \mu \mathrm{L}$. The thermo cycler schedule for the second reaction was as follows: denaturation at $94^{\circ} \mathrm{C}$ for 3 min, followed by 35 denaturation cycles at $94^{\circ} \mathrm{C}$ for $1 \mathrm{~min}$, annealing at $58^{\circ} \mathrm{C}$ for $2 \mathrm{~min}$, and extension at $72^{\circ} \mathrm{C}$ for $1 \mathrm{~min}$ and 30 s (CARLOS et al., 2011).

The positive control was dog blood tested positive for E. canis, as confirmed previously by sequencing (GUEDES et al., 2015). Ultrapure water was used as the negative control. The results were analyzed using descriptive statistics.

\section{Results}

The nested PCR results showed that, out of the 66 animals with bilateral uveitis, 35 (53\%) tested positive for E. canis. Of 69 eyes of the 35 animals,
57 (82.6\%) eyes had iridocyclitis, posterior uveitis, or panuveitis, while $12(17.4 \%)$ showed uveitis with secondary glaucoma.

Some of the ophthalmic signs observed in the animals that tested positive for uveitis without secondary glaucoma were as follows: purulent secretion, photophobia, blepharospasm, chemosis, conjunctival hyperemia, injection of the episcleral vessels; neovascularization, ulcer and corneal edema, persistent miosis, and decrease or increase in lacrimal production (Figure 1). All animals with uveitis (Figure 2) exhibited more than two concomitant signs, in addition to IOP reduction.

Some of the ophthalmic signs visible in the animals with uveitis and secondary glaucoma, in addition to those mentioned above, were as follows: buphthalmia, pigmentation, fracture of Descemet's membrane, and irresponsive mydriasis with diminished reflexes (Figure 1). All the animals with uveitis and secondary glaucoma (Figure 3) exhibited more than two concomitant signs, in addition to elevated IOP or near maximum limits of normality for the species.

Figure 1. Frequency of clinical signs of the 35 dogs infected with E. canis, and diagnosed with uveitis and glaucoma secondary to uveitis.

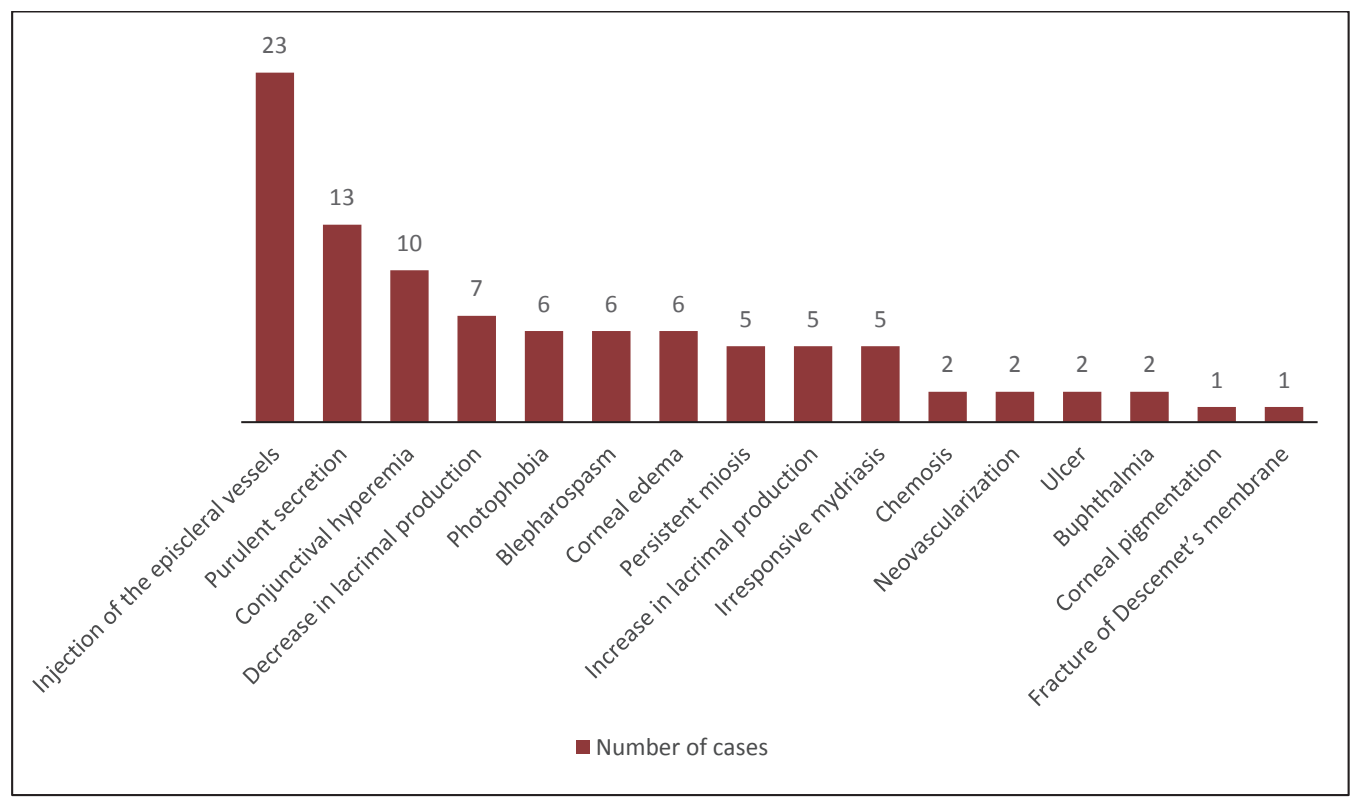


Figure 2. Eye of a dog with uveitis, showing conjunctive chemosis (blue arrow), episcleral injection (green arrow), corneal neovascularization (yellow arrow), corneal edema (white arrow), and purulent secretion (black arrow).

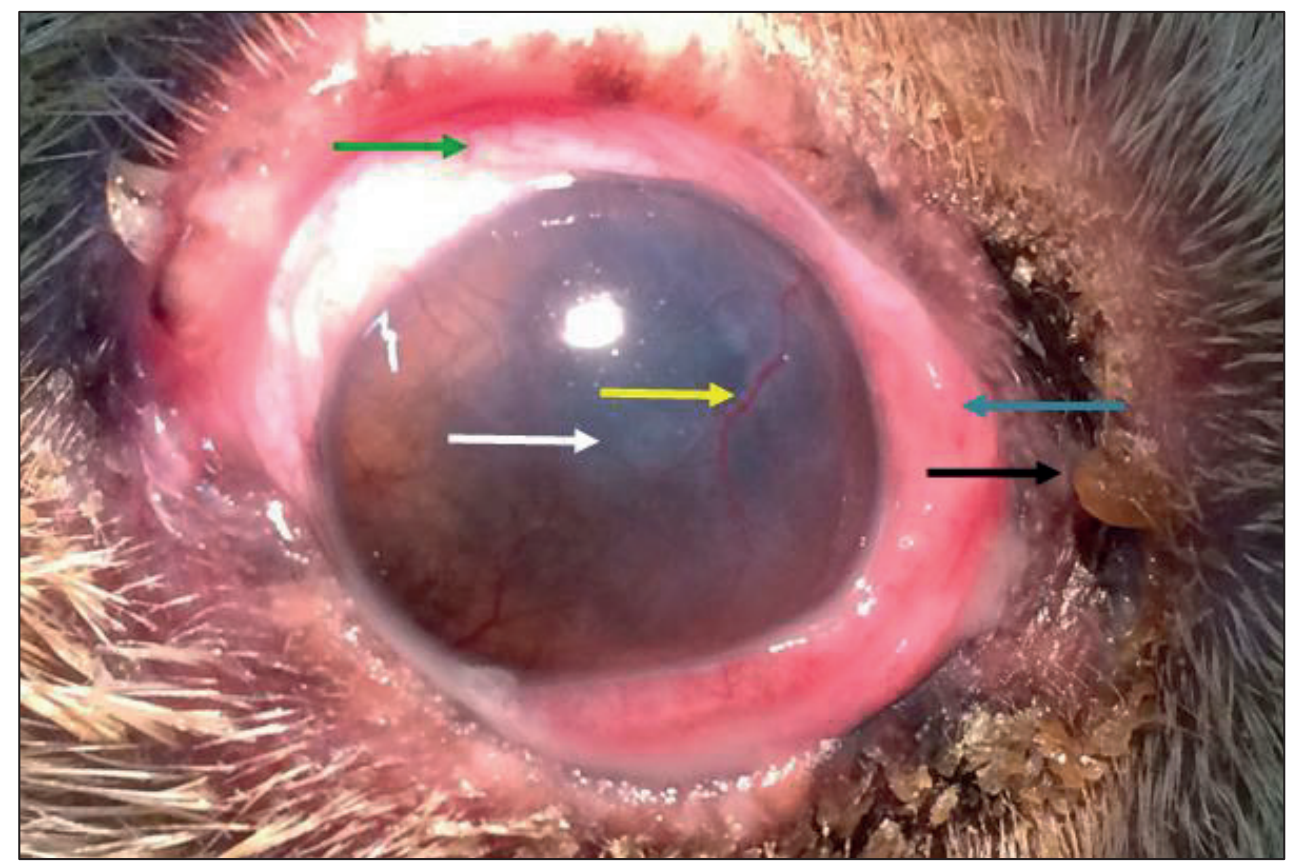

Source: Personal archive (2015).

Figure 3. Eye of a dog with glaucoma secondary to uveitis, showing engorged episcleral vessels (green arrow), corneal neovascularization (yellow arrow), fracture of Descemet's membrane (white arrow), diffuse corneal edema (blue arrow), and purulent secretion (black arrow).

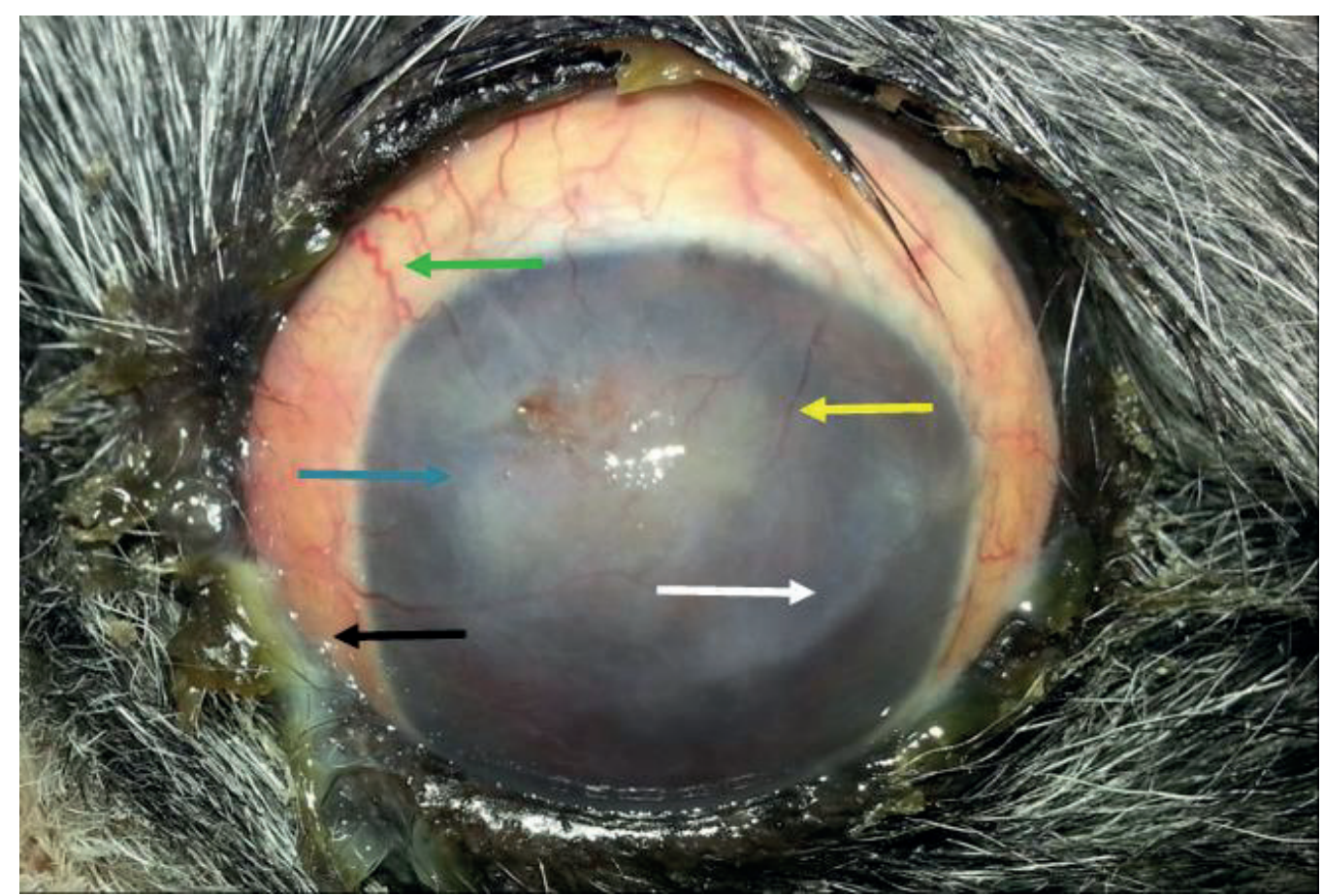

Source: Personal archive (2015). 


\section{Discussion}

In the present study, the inclusion criterion was established for animals diagnosed with bilateral uveitis, since this is the most reported form of identification of ophthalmic disease secondary to infection by E. canis (LEIVA et al., 2005; KOMNENOU et al., 2007).

The ophthalmic signs observed in the animals, such as blepharospasm, photophobia, epiphora, corneal edema, and persistent miosis, have already been described by other authors in animals with CME (KOMNENOU et al., 2007; ORIÁ et al., 2008). In addition, the presence of purulent secretion and episcleral injection has been described (ORIÁ et al., 2008; WALSER-REINHARDT et al., 2012).

Secondary glaucoma may occur in dogs with uveitis because of CME caused by obstruction of the trabecular meshwork by increased cellularity in the anterior chamber or by formation of synechiae that obstruct adequate drainage of the aqueous humor (ORIÁ et al., 2008). Among the cases of secondary glaucoma diagnosed in this study, three animals showed IOP values within the normal range, who presented $15 \pm 2 \mathrm{mmHg}, 18 \pm 2 \mathrm{mmHg}$ and $23 \pm 2 \mathrm{mmHg}$ of mean. Such a finding may be due to intensification of aqueous humor drainage via the uveal-scleral pathway and/or reduction of the production of aqueous humor by the inflamed ciliary body. With the chronicity of the disease, this compensatory pathway tends to become unbalanced to such an extent that the IOP exceeds the normal values (ORIÁ et al., 2004; PLUMMER et al., 2013).

Previous studies on the prevalence of E. canis in canine populations evaluated using nested PCR in the southern regions of Bahia have reported lower incidences (CARVALHO et al., 2008; CARLOS et al., 2011; GUEDES et al., 2015). However, in the present study, we observed a higher prevalence; the values are closer to those observed by Oriá et al. (2008), who found $66.67 \%$ positivity by using the indirect immunofluorescence test. The authors also found $88.27 \%$ positivity by using ELISA. However, another study on animals with uveitis considered the percentage of infecto-contagious causes against all other possible causes to be low, even when E. canis stood out in approximately $40 \%$ of the infectious causes (MASSA et al., 2002).

The differences between the percentages reported previously and those found in the present study can be explained; molecular techniques guarantee greater sensitivity when the disease is in its acute stage, which is when the animals become carriers of the pathogen. However, serological tests determine higher prevalence in studies, but cannot distinguish between pre-exposure and active infection, not always indicating that the animal is infected (MASSA et al., 2002; KOMNENOU et al., 2007; ORIÁ et al., 2008; GUEDES et al., 2015). Therefore, in animals with signs of uveitis, PCR provides accurate results because of the sensitivity and specificity of the test.

\section{Conclusions}

The nested PCR test was considered satisfactory for the diagnosis of animals infected by E. canis, and the obtained data demonstrated a high occurrence of ehrlichiosis in the animals with uveitis.

\section{Acknowledgements}

We would like to thank the State University of Santa Cruz (UESC) for offering development conditions for this research as well as for the scientific initiation scholarships and financial aid for the project; Fundação de Amparo à Pesquisa do Estado da Bahia (FAPESB) for financing the project; and the Coordination of Improvement for Higher Education Personnel (CAPES) for the graduate studies scholarship.

\section{References}

BISTNER, S. Allergic - and immunologic - mediated diseases of the eye and adnexae. Veterinary Clinics of 
North America: Small Animal Practice, Philadelphia, v. 24, n. 4, p. 711-734, 1994.

CARLOS, R. S. A.; CARVALHO, F. S.; WENCESLAU, A. A.; AlMOSNY, N. R. P.; ALBUQUERQUE, G. R. Risk factors and clinical disorders of canine ehrlichiosis in the South of Bahia, Brazil. Revista Brasileira de Parasitologia Veterinária, Jaboticabal, v. 20, n. 3, p. 210214, 2011.

CARVAlHO, F. S.; WENCESLAU, A. A.; CARLOS, R. S. A.; ALBUQUERQUE, G. R. Epidemiologic and molecular study of Ehrlichia canis in dogs in Bahia, Brazil. Genetics and Molecular Research, Ribeirão Preto, v. 7, n. 3, p. 657-662, 2008.

DAGNONE, A. S.; MORAIS, H. S. A.; VIDOTTO, M. C.; JOJIMA, F. S.; VIDOTTO, O. Ehrlichiosis in anemic, thrombocytopenic, or tick-infested dogs from a hospital population in South Brazil. Veterinary Parasitology, Amsterdam, v. 117, n. 4, p. 285-290, 2003.

DUMLER, J. S.; BARBET, A. F.; BEKKER, C. P.; DASCH, G. A.; PALMER, G. H.; RAY, S. C.; RIKIHISA, Y.; RURANGIRWA, F. R. Reorganization of genera in the families Rickettsiaceae and Anaplasmataceae in the order Rickettsiales: unification of some species of Ehrlichia with Anaplasma, Cowdria with Ehrlichia and Ehrlichia with Neorickettsia, descriptions of six new species combinations and designation of Ehrlichia equi and HGE agent as subjective synonyms of Ehrlichia phagocytophila. International Journal of Systematic and Evolutionary Microbiology, London, v. 51, n. 6, p. $2145-$ 2165, 2001 .

GUEDES, P. E. B.; OLIVEIRA, T. N. A.; CARVALHO, F. S.; CARLOS, R. S. A.; ALBUQUERQUE, G. R.; MUNHOZ, A. D.; WENCESLAU, A. A.; SILVA, F.

L. Canine ehrlichiosis: prevalence and epidemiology in northeast Brazil. Brazilian Journal Veterinary Parasitology, Jaboticabal, v. 24, n. 3, p. 115-121, 2015.

HARRUS, S.; DAY, M. J.; WANER, T.; BARK, H. Presence of immune-complexes, and absence of antinuclear antibodies, in sera of dogs naturally and infected with Ehrlichia canis. Veterinary Microbiology, Barcelona, v. 83, n. 4, p. 343-349, 2001.

HENDRIX, D. V. H. Veterinary ophthalmology: disease and surgery of the canine anterior uvea. $5^{\text {th }}$ ed. Oxford: John Wiley \& Sons, 2013. 2264 p.

IQBAL， Z; CHAICHANASIRIWITHAYA, W.; RIKIHISA, Y. Comparison of PCR with other tests for early diagnosis of canine ehrlichiosis. Journal of Clinical Microbiology, Barcelona, v. 32, n. 7, p. 1658-1662, 1994.

KOMNENOU, A. A.; MYLONAKIS, M. E.; KOUTI, V.; TENDOMA, L.; LEONTIDES, L.; SKOUNTZOU,
E.; DESSIRIS, A.; KOUTINAS, A. F.; OFRI, R. Ocular manifestations of natural canine monocytic ehrlichiosis (Ehrlichia canis): a retrospective study of 90 cases. Veterinary Ophthalmology, Medford, v. 10, n. 3, p. 137$142,2007$.

LABARTHE, N.; PEREIRA, M. C.; BARBARINI, O.; MCKEE, W.; COIMBRA, C. A.; HOSKINS, J. Serologic prevalence of Dirofilaria immitis, Ehrlichia canis, and Borrelia burgdorferi infections in Brazil. Veterinary Therapeutics, Bethesda, v. 4, n. 1, p. 67-75, 2003.

LEIVA, M.; NARANJO, C.; PEÑA, M. T. Ocular signs of canine monocytic ehrlichiosis: a retrospective study in dogs from Barcelona, Spain. Veterinary Ophthalmology, Medford, v. 8, n. 6, p. 387-393, 2005.

MARTIN, C. L.; STILES, J. Infectious diseases of dog and cat: ocular infection. $2^{\text {th }}$ ed. Philadelphia: W. B. Saunders, 1998. 934 p.

MASSA, K. L.; GILGER, B. C.; MILlER, T. L.; DAVIDSON, M. G. Causes of uveitis in dogs: 102 cases (1989-2000). Veterinary Ophthalmology, Medford, v. 5, n. 2, p. 93-98, 2002.

MURPHY, G. L.; EWING, S. A.; WHITWORTH, L. C.; FOX, J. C.; KOCAN, A. A. A molecular and serologic survey of Ehrlichia canis, E. chaffeensis and E. ewingii in dogs and ticks from Oklahoma. Veterinary Parasitology, Amsterdam, v. 79, n. 4, p. 325-339, 1998.

ORIÁ, A. P.; DÓREA NETO, F. A.; MACHADO, R. Z.; SANTANA, A. E.; GUERRA, J. L.; SILVA, V. L. D.; LAUS, J. L. Ophthalmic, hematologic, serologic and histologic findings in dogs with suspected Ehrlichia canis infection. Revista Brasileira de Ciência Veterinária, Niterói, v. 15, n. 2, p. 94-97, 2008.

ORIÁ, A. P.; PEREIRA, P. M.; LAUS, J. L. Uveitis in dogs infected with Ehrlichia canis. Ciencia Rural, Santa Maria, v. 34, n. 4, p. 1289-1295, 2004.

PLUMMER, C. E.; REGNIER, A.; GELATT, K. N. Veterinary ophthalmology: the canine glaucomas. $5^{\text {th }}$ ed. Oxford: John Wiley \& Sons, 2013. 2264 p.

RODRIGUEZ-VIVAS, R. I.; ALBORNOZ, R. E. F.; BOLIO, G. M. E. Ehrlichia canis in dogs in Yucatan, México: seroprevalence, prevalence of infection and associated factors. Veterinary Parasitology, Amsterdam, v. 127, n. 1, p. $75-79,2005$.

TALIERI, I. C.; BRUNELLI, A. T. J.; ORIA, A. P.; LAUS, J. L. Exame oftálmico em cães e gatos. Revista Clínica Veterinária, São Paulo, v. 1, n. 61, p. 42-54, 2006.

VIEIRA, R. F. C.; BIONDO, A. W.; GUIMARÃES, A. M. S.; SANTOS, A. P.; SANTOS, R. P.; DUTRA, L. H.; DINIZ, P. P. V. P.; MORAIS, H. A.; MESSICK, J. 
B.; LABRUNA, M. B.; VIDOTTO, O. Ehrlichiosis in Brazil. Revista Brasileira de Parasitologia Veterinária, Jaboticabal, v. 20, n. 1, p. 1-12, 2011.

WALSER-REINHARDT, L.; SCHAARSCHMIDTKIENER, D.; FORSTER, J. L.; SPIESS, B. M. Direct detection of Ehrlichia canis by PCR in the conjunctiva of a dog with bilateral anterior uveitis. Schweizer Archiv für Tierheilkunde, Berna, v. 154, n. 4, p. 149-152, 2012.
WEN, B.; RIKIHISA, Y.; MOTT, J. M.; GREENE, R.; KIM, H. Y.; ZHI, N.; COUTO, G. C.; UNVER, A.; BARTSCH, R. Comparison of nested PCR with immunofluorescent-antibody assay for detection of Ehrlichia canis infection in dogs treated with doxycycline. Journal of Clinical Microbiology, Barcelona, v. 35, n. 7, p. 1852-1855, 1997. 